\title{
INTERNAL CONTROL EFFECTIVENESS \& ITS RELATIONSHIP WITH FINANCIAL PERFORMANCE
}

\author{
Dr. Zahid Ali Channar1 \\ Dean, Faculty of Management \& Social Sciences, Institute of Business \\ \& Technology, Kararachi \\ Maha Khan² \\ Faculty of Commerce Economics and Management Sciences, Isra University \\ Hyderabad. \\ Irfan Haider Shakri3 \\ Lecturer, Institute of Business \& Technology, Karachi
}

\begin{abstract}
Purpose: This research attempts to investigate the functionality of each of the five Internal control components, effectiveness of the control system and its relationship with financial performance.

Methodology: Sample size for this research is 210 respondents comprising of employees from 6 Banks in Hyderabad: NBP and Sindh bank from the public sector, $M C B$ and HBL from the private sector, Meezan bank and Bank Alfalah as Islamic banks. In this study, internal control is measured by the five components whereas financial performance is measured through three profitability ratios. Data is collected through primary as well as secondary sources. The primary source used is questionnaire taken from a combination of instruments developed by Baker, Castro, Labrena \& Meyer (2005). Secondary source used are the financial statements of the sample banks for a period of four years. Return on Asset (ROA), Return on Equity (ROE), Profit expense ratio (PER) are the profitability ratios used to measure the financial performance. Data was analyzed using the Statistical Package for Social Scientists (SPSS). The statistical methods of correlation and one-way ANOVA were used for the testing of the research hypotheses.

Findings: Results showed that Internal control effectiveness is strongest in private banks, followed by public banks and weakest in islamic banks, although the difference is not statistically large, but slight variation exists. Moreover, private banks had a high level of financial performance, public banks had moderate level of financial performance whereas islamic banks were found to have low financial performance. Hence it was concluded that Internal control effectiveness has a positive relationship with the Financial performance of the banks.

Practical Implications: The detailed evaluation and understanding of the Internal control system effectiveness and its components provides valuable insights to managers and employees of how they can manage or improve their control systems in order to achieve greater operational as well as financial performance.
\end{abstract}

Keywords : Internal Control Effectiveness, Control components, Financial performance, Public banks, Private banks and Islamic banks

\section{Jel Classification: D920, E220, F210} \footnotetext{
and the management of the Institute of Business \& Technology (IBT)
1. Dr Zahid Ali Channar
2. Maha Khan
:drzahidalic@gmail.com
3. Irfan Haider Shakri
: afaq.maha@hotmail.com
: irfanshakri@gmail.com

(C) IBTJBS is published by the Institute of Business and Technology (IBT).

Main Ibrahim Hydri Road, Korangi Creek, Karachi-75190, Pakistan.
}

* The material presented by the author does not necessarily portray the viewpoint of the editors 


\section{INTRODUCTION}

In the recent years, internal controls and deliberate reporting on these controls has received a great amount of interest in the accounting literature as well as accounting profession (Hossain et al., 1995; McMullen et al., 1996). Verschoor (1999) defines internal control as a term used by management to ensure that the firm accomplishes its financial as well as other objectives. Furrugia (2002) defines internal control as the system of the firm and the collaborated activities used to secure assets from loss by errors, measure the precision and reliability of data to be utilized by the management in decision making, to promote operational effectiveness and ensure conformity to rules and regulations in areas where financial departments have direct or indirect duties. The internal control system is the consideration of the management, but the control system should be thoroughly disseminated for proper implementation by the employees. Internal control supports the utilization of resources and hence assists the management to accomplish the organization's objectives (Knechel et al., 2007). Doyle et al. (2006) states that organizations are frequently exposed to risks and the risks it faces also change continually due to which the control systems help in monitoring and controlling risk instead of removing it. Corporations experience considerably reduced cost of debt financing by improving the quality of its control systems (Anderson et al., 2004). Weakness or lax in internal control systems cause ineffective allocation of resources to definite priorities and to ensure that worth for the money will be achieved in public spending (Lawson, De Renzio and Umarji, 2006).

Control environment, risk assessment, control activities, information and communication and monitoring are the five interconnected components of internal control (Rezaee,1995; Konrath, 1996; Yang and Guan, 2004; Hayes et al., 2003). According to Konrath (1999), Control Environment considerably influences and determines organizational tone, has a significant impact on the perception relating to control system and also serves as a foundation for effective functioning of the internal control system. Furrugia (2002) describes risk assessment as the procedure employed by the management of the firm to handle the risks that act as hurdles in accomplishing the objectives. Risk assessment is the identification, assessment and supervision of risks. These risks involve misstatement of financial data or even the inefficient utilization of assets (Jones, 2007). Control activities comprise a variety of tasks such as agreements, endorsements, certification, reconciliation, conducting reviews, providing security, and the development and maintenance of data which serve as proof of implementation of these activities along with suitable documentation (Walker 1999). Britnell (2001) defines information and communication as procedures adopted by a firm to gather, process and report authentic information within the appropriate time to ensure employees perform their duties punctually. Information and communication component of control systems enable timely accomplishment of reporting objectives by collecting and communicating relevant information within the appropriate timeframe (Gaskill,2000). Effective information 
and communication systems generate reports enclosing operational, compliance and financial information that enable to run and manage a business. these reports contain internal as well as external data, circumstances and actions to enlighten decision making and external reporting (Simmons, 1995). Jones (2008) defines monitoring as the procedure of evaluating the quality of a system's performance with the passage of time. Continued monitoring activities are incorporated into the usual frequent activities of the firm (Simmons, 1995).

Performance is described as the measurement of actual output of an organization against its expected outputs or goals (Goodwin, 2003). Ofley (2003) points out the significance of financial performance as it motivates and helps in managing the operation of an organization. Managerial decision making involves extensive use of financial ratios (Howard Finch, 2005). According to Van Horne (2005), the profit on assets of an entity after all expenditures and taxes is known as Return on assets. Van Horne (2005) defines Return on equity as the profit belonging to the shareholders after deduction of all expenditures and taxes. Profit to expenses ratio measures the profit of an entity respective to the operating expenditures (Samad and Hassan, 2000).

\section{REVIEW OF LITERATURE}

Rokeya and Muhammad (2011) carried out a critical assessment of Internal control systems in firms in their research paper on "Evaluation of Internal Control Structure: Evidence from Six listed Banks in Bangladesh". The study concludes that the banks under observation effectively accomplished the objectives and there is least amount of deviation in the achievement of control objectives.

Another research conducted by Angella and Eno (2009) on the topic "Evaluation of Internal Control Systems: A Case Study from Uganda" assesses the internal control mechanisms adopted by the regional member countries of African Development Bank Group for the purpose of management of Public sector project financing. The research paper concludes that some components of the control system are not properly implemented.

Research article by Akosile (2013) namely "A Comparative assessment of Internal Control System in Public and Private Universities in South-West, Nigeria" studied the comparative evaluation of internal control systems in public and private universities of Nigeria. The results of the analysis show that the control systems are not different in public and private universities.

Mafiana Enwelum Azu carried out a quantitative and comparative study on the topic "Examining the Relationships between Internal Control Effectiveness and Financial Performance in the Nigerian Banking Industry" in 2013. The findings showed a significant positive correlation between Internal control effectiveness and financial performance earlier as well as later than the Central Bank of Nigeria intervention. Another research on the topic "How does Internal control effectiveness create reliability of Financial reporting? An empirical research on Thai listed firms" was conducted by 
Kanyamon and Sumalee in 2011. The findings showed that internal control effectiveness positively influence the financial information reliability. it was concluded that risk management, compliance quality and monitoring adequacy considerably influence internal control effectiveness.

Fawzi and Atala (2012) examine the relationship between internal control components and the effectiveness of audit program in Jordan in their article "Internal Control and Audit Program Effectiveness: Empirical Evidence from Jordan". It was found that risk assessment significantly contributed to the performance of the audit program whereas control environment and control activity had no impact on audit program performance.

Another research by Joseph, Ransome and Victoria (2012) titled "Effectiveness of Internal Control Systems of Listed Firms in Ghana" investigates the performance of control systems practiced in firms listed on the Ghana Stock Exchange. The result of the effectiveness scores of the firms concluded that internal control systems had moderate performance levels, but could not be considered as satisfactory. It was also found that out of the five components of internal control, control environment showed the greatest amount of effectiveness.

The article "Analysis of the relationship between listed companies' earnings quality and Internal control information disclosure" by Jianfei and Lu (2011) examines the relationship between earnings quality and internal control information disclosure. The results show that there is a positive relationship between the earnings quality and the level of internal control information disclosure. This means that the greater the company's EPS, the better will be the company's performance and hence the company will be more willing to reveal its control information in detail.

In 2012 Eko Suyono and Eko Hariyanto carried out research based on "Relationship between Internal Control, Internal Audit and Organization Commitment with Good Governance: Indonesian Case". Data was evaluated using multiple linear regression analysis and the result showed that there is positive relationship between internal control, internal audit, organization commitment and good governance.

Uket and Joseph (2012) carried out research on "The impact of Internal Control Design on Bank's ability to investigate Staff fraud, and Lifestyle and Fraud detection in Nigeria". It was deduced that most Nigerian banks do not seriously consider the lifestyle of their personnel and that majority of the staff believed that efficient and effective control systems will assist in identifying the staff fraud in this particular sector.

"Internal Control on Cash collection: A case of the Electricity Company of Ghana (ECG) Ltd, Accra East Region" is a research study conducted by Francis and Samuel (2013). It was also concluded that no control system is bound to be completely efficient or fault-free. It is very important that the management overrides the control system and frequently evaluates the control system for best performance.

The study of Olaoye (2009) on "The impact of Internal Control System in banking sector in Nigeria" was carried out in order to authenticate the perception that an effective 
control structure is the most appropriate method for reducing and detecting deception in the banking sector. The results proved that Internal control systems play a significant role in detecting fraud and preventing it in the banking sector of Nigeria.

Qaisar and Javid (2012) carried out a research on "Internal Control System: Analyzing Theoretical Perspective and Practices". It was discovered that a well established and successfully implemented control system assists in proper utilization of resources and a framework for operations for every kind of organization. It was deduced that control systems generate reliable financial data which assist stakeholders in proper decisionmaking.

The research by Emmanuel and Agyapong (2013) namely "Internal Control in small and Microenterprises in the Vhembe District, Limpopo province, South Africa" investigated the efficiency of control systems in the SMEs, specifically in the Vhembe district in South Africa. According to the result, the efficiency of the control systems practiced by the small business sector was quite low, with only $45 \%$ of the sample firms having satisfactory control systems. The findings of the research also suggested that small business should be encouraged and promoted to assist growth and expansion that will further enable increased efficiency of the internal control system.

The research carried out by Dr. Tamer and Dr. Daas (2013) titled "Assess the extent of the application internal control elements evaluation and its effectiveness when doing Audit process- An analytical study on the Jordanian Banks auditors" focused on studying internal control components with an accounting perspective. The result obtained proved that auditors evaluate the efficiency of internal control during the auditing process.

The research paper by Ngwenya (2013) on the topic "Application of Internal Controls in NGOs: Evidence from Zimbabwe" investigated the degree to which NGOs in Zimbabwe implement internal controls in their procedures. The result of the study concluded that strong internal control structures are adopted by the NGOs in Zimbabwe with respect to control environment, Control activities and monitoring.

"Stakeholders perception on the effectiveness of internal control system on financial accountability in the Nigerian public sector" conducted by Babatunde and Shakirat (2013) aims to prove the perception that effective internal control system plays a vital role in ascertaining financial accountability, specifically in the Nigerian public sector. Results prove that there exists a significant correlation in the respondent's perception that financial accountability is significantly affected by internal control systems and that application of penalty for violation of moral conduct impacts conformity with internal control.

\subsection{Problem Statement}

Despite the control systems put in place by the banks, these banks still experience liquidity problems, inefficient allocation of resources, delay in preparation of financial reports, malfunctioning and fraud in use of assets of the banks 


\subsection{Aim of Study}

By identifying the functionality of each internal control component and the relationship between the effectiveness of the control system and financial performance it may be possible to develop significant recommendations for improving the financial performance of the banks by modifying the control system accordingly. The findings of this research will provide a knowledge-based method that will aid in decision making for mangers and help recognize internal control faults to prevent any negative consequences.

\subsection{Objectives}

1. To determine the functionality of individual components of internal control systems in the Banks

2. To measure the financial performance of the Banks

3. To examine the relationship between the functionality of internal control components and financial performance of the Banks

\subsection{Hypotheses}

H1: All Internal control components are effective in Private banks

H2: All Internal control components are effective in Public banks

H3: All Internal control components are effective in Islamic banks

H4: Internal control effectiveness varies significantly amongst different sectors of banks (Public, private and islamic).

H5: Different sectors of banks have varying Financial performances.

H5(a): Different sectors of banks have varying Return on Asset (ROA)

H5(b): Different sectors of banks have varying Return on Equity (ROE)

H5(c): Different sectors of banks have varying Profit expense ratio (P/E)

\subsection{Scope of Research}

The research will focus on measuring the level of effectiveness of internal control systems and examine its relationship with the financial performance of banks in Hyderabad belonging to three different sectors. A total of six banks have been selected for the study: two belonging to public sector, 2 belonging to private sector and the other two will comprise of Islamic banks.

\section{METHODOLOGY}

\subsection{Sample Size}

A total of six banks have been selected for the study: National Bank of Pakistan (NBP) and Sindh Bank have been selected for the public sector, Muslim Commercial Bank (MCB) and Habib Bank Limited (HBL) have been selected for the private sector whereas Bank AlFalah and Meezan Bank will represent Islamic banks in this research. The sample size for this research will be 210 respondents, 35 employees from each bank.

\subsection{Data Source}

Primary source used in this research was a Close-ended questionnaire. It consists of 
Categorical variables which consist of Name, Gender, Age and Qualification. The Continuous Variables included in the questionnaire comprise of Control environment, risk assessment, control activity, information and communication, monitoring. The questionnaire for this research was taken from a combination of instruments developed by Baker, Castro, Labrena \& Meyer (2005). Financial Performance is measured using financial statements (Balance sheet, income statement) of the sample banks for a period of four years $(2010,2011,2012,2013)$.

\subsection{Data Analysis}

Statistical Package for Social Scientists (SPSS) 16.0 version was used for analysis of data. As the data is not normally distributed, Spearman's rho correlation is used in this study. The two continuous variables measured in this research are components of internal control and effectiveness of the control system. The statistical test of Analysis of Variance (ANOVA) was used to assess and appraise the different sources of variance amongst the data set. In this test, the categorical variable used was type of bank and continuous variable used was effectiveness of the control system. In this study, the financial ratios used to measure the financial performance of banks are profitability ratios. The following Profitability ratios are used for this purpose:

$$
\begin{aligned}
& \text { - } \\
& \text { - } \\
& \text { - }
\end{aligned}
$$

\section{RESULTS AND ANALYSIS}

\subsection{Correlation}

\section{H1: All Internal control components are effective in Private banks.}

Spearman's rho correlation technique was conducted to analyze whether each component of internal control had a significant impact on the effectiveness of the control system in the two Private banks (MCB and HBL). (See Table I)

Table I shows that relationship between independent and dependent variable is positive and strong in both the Private banks. The strength of the relationship between all the five components and effectiveness of the control system is greater than 0.5 and significant as the $\mathrm{P}$ value is .000 which is greater than 0.05 . Therefore, the alternative hypothesis is accepted and the null hypothesis is rejected for Private banks.

\section{H0: All Internal control components are effective in Private banks. HA: All Internal control components are not effective in Private banks.}

\section{H2: All Internal control components are effective in Public banks.}

Spearman correlation technique was conducted to analyze whether each component of internal control had a significant impact on the effectiveness of the control system in the two Public banks (Sindh Bank and NBP). (See Table II) 
Table II shows that relationship between independent and dependent variable is positive and but not strong in both the Public banks. The strength of the relationship between three components (control environment, risk assessment, information and communication) and effectiveness of the control system was strong and positive in both the banks with $\mathrm{P}$ value of .000 which is significant. One component i.e. monitoring was found to be effective in only one of the two banks. In addition, control activity was found to have the weakest relationship with effectiveness of the control system in both the banks. Hence, based on the results we accept null hypothesis and reject alternative hypothesis.

H0: All Internal control components are not effective in Public banks. HA: All Internal control components are effective in Public banks.

H3: All Internal control components are effective in Islamic banks. Spearman correlation technique was conducted to analyze whether each component of internal control had a significant impact on the effectiveness of the control system in the two Islamic banks (Bank AlFalah and Meezan). (See Table III) Table III shows that relationship between independent and dependent variable is positive but weak in both the Islamic banks. Monitoring is the only component found to have positive and significant relationship in both the banks. Control environment and risk assessment had a moderate relationship in one whereas as weak relationship in the other bank. The other two components (control activity and information and communication) had a weak and non-significant relationship as the $\mathrm{P}$ value is greater than 0.05 for both the banks. Therefore, based on the above values we accept null hypothesis and reject alternative hypothesis.

Ho: All Internal control components are not effective in Islamic banks. HA: All Internal control components are effective in Islamic banks.

\section{H4: Internal control effectiveness varies significantly amongst different sectors of banks (Public, private and Islamic).}

One-way ANOVA test was conducted to compare and contrast the effectiveness of the control system amongst public, private and islamic banks. For this test one categorical and continuous variable is required. In this case, categorical variable is bank which is divided into three categories i.e. public, private and islamic banks whereas the continuous variable is effectiveness of the internal control system. (See Table IV and V)

Table IV shows that the mean score of Islamic banks is 98.82, Public banks is 102.78 and Private banks is 105.57. This shows that the Internal control effectiveness is greatest in private, followed by that in public and the least in private banks. In Table V, SPSS illustrates three rows which show between groups, within groups and total sums of squares. The value of SSbetween is 1607.32 , SSwithin is 12132.87 and SStotal is 
13740.19. The mean square (MS) between groups value 803.66 is obtained by dividing SSbetween 1607.32 with dfbetween (degree of freedom) 2. Similarly, dividing SSwithin 12132.87 with dfwithin 207 yields Mean square (MS) within groups equal to 58.61. As Table IV shows the significance value of 0.082 which is greater than 0.05 . Hence, we accept null hypothesis and reject alternative hypothesis.

Ho: Internal control effectiveness does not vary significantly amongst different sectors of banks (Public, private and Islamic). $H_{A}$ : Internal control effectiveness varies significantly amongst different sectors of banks (Public, private and Islamic).

\section{H5: Different sectors of banks have varying Financial performances.} H5(a) : Different sectors of banks have varying Return on Asset (ROA)

One-way ANOVA test was conducted to compare and contrast the financial performance in terms of return on asset amongst public, private and islamic banks. For this test one categorical and continuous variable is required. In this case, categorical variable is bank which is divided into three categories i.e. public, private and islamic banks whereas the continuous variable is financial performance in terms of return on asset. (See Table VI and VII)

Table VI shows that the mean score of Islamic banks is 0.0125 , Public banks is 0.0175 and Private banks is 0.0200 . This shows that the financial performance in terms of Return in Assets is greatest in private, followed by that in public and the least in private banks. In Table VII, SPSS illustrates three rows which show between groups, within groups and total sums of squares. The value of SSbetween is 0.000 , SSwithin is 0.002 and SStotal is 0.002 . The mean square (MS) between groups value 0.000 is obtained by dividing SSbetween 0.000 with dfbetween (degree of freedom) 2. Similarly, dividing SSwithin 0.002 with dfwithin 21 yields Mean square (MS) within groups equal to 0.000 . Table VI shows the significance value of 0.241 which is greater than 0.05 . Hence, we accept null hypothesis and reject alternative hypothesis.

Ho: Different sectors of banks do not have significant variations in Return on Asset (ROA)

HA: Different sectors of banks have significant variations in Return on Asset (ROA)

\section{H5(b) : Different sectors of banks have varying Return on Equity (ROE)}

One-way ANOVA test was conducted to compare and contrast the financial performance in terms of return on equity amongst public, private and islamic banks. For this test one categorical and continuous variable is required. In this case, categorical variable 
is bank which is divided into three categories i.e. public, private and islamic banks whereas the continuous variable is financial performance in terms of return on equity. (See Table VIII and IX)

Table VIII shows that the mean score of Islamic banks is 0.2438 , Public banks is 0.4725 and Private banks is 1.4038. This shows that the financial performance in terms of Return on Equity is greatest in private, followed by that in public and the least in private banks. In Table IX, SPSS illustrates three rows which show between groups, within groups and total sums of squares. The value of SSbetween is 6.040, SSwithin is 8.324 and SStotal is 14.365. The mean square (MS) between groups value 3.020 is obtained by dividing SSbetween 6.040 with dfbetween (degree of freedom) 2. Similarly, dividing SSwithin 8.324 with dfwithin 21 yields Mean square (MS) within groups equal to 0.396 . Table VIII shows the significance value of 0.751 which is greater than 0.05 . Hence, we accept null hypothesis and reject alternative hypothesis.

H0: Different sectors of banks do not have significant variations in Return on Equity.

HA: Different sectors of banks have significant variations in Return on Equity.

\section{H5(c) : Different sectors of banks have varying Profit expense ratio (PER)}

One-way ANOVA test was conducted to compare and contrast the financial performance in terms of return on equity amongst public, private and islamic banks. For this test one categorical and continuous variable is required. In this case, categorical variable is bank which is divided into three categories i.e. public, private and islamic banks whereas the continuous variable is financial performance in terms of Profit expense ratio. See Table $\mathrm{X}$ and $\mathrm{XI}$ )

Table X shows that the mean score of Islamic banks is 0.4875 , Public banks is 1.0959 and Private banks is 1.3612. This shows that the financial performance in terms of Profit expense ratio is greatest in private, followed by that in public and the least in private banks. In Table XI, SPSS illustrates three rows which show between groups, within groups and total sums of squares. The value of SSbetween is 3.209, SSwithin is 7.080 and SStotal is 10.289 . The mean square (MS) between groups value 1.605 is obtained by dividing SSbetween 3.209 with dfbetween (degree of freedom) 2. Similarly, dividing SSwithin 7.080 with dfwithin 21 yields Mean square (MS) within groups equal to 0.337 . Table I0 shows the significance value of 0.636 which is greater than 0.05 . Hence, we accept null hypothesis and reject alternative hypothesis.

\section{Ho: Different sectors of banks do not have significant variations in Profit Expense ratio. \\ HA: Different sectors of banks have significant variations in Profit Expense ratio.}




\section{CONCLUSION AND RECOMMENDATIONS}

This study focuses on the banking sector of Hyderabad and attempts to measure the level of effectiveness of the internal control system of banks belonging to different sectors and to establish a relationship between the control system effectiveness and financial performance of the banks.

In the Private sector, it was found that all the five components of internal control namely control environment, risk assessment, control activity, information and communication and monitoring had a strong and positive relationship with the effectiveness of the control system in the banks. As far as the public sector is concerned, it was found that only three out of the five components were found to be effective whereas poor functionality of the other two components i.e. control activity and monitoring lead to the absence of a robust system to ensure duties are performed on time and management directives are duly carried out. These reasons also explain the unsatisfactory level of financial performance of public banks as compared to private banks. The internal control system was found to be least effective in the Islamic banks as only one component of the control system i.e. monitoring had a significant relationship with the effectiveness of the control system but the other four components do not function as stipulated. Hence, the low financial performance of Islamic banks may be explained by the weaknesses in the control components. A comparative analysis of the effectiveness of the Internal control system of Private, public and Islamic banks is conducted and the results indicate that the control system is found to be the strongest in private banks, followed by that in public banks and weakest in islamic banks. Although the difference is found not to be statistically large, but slight variation exists in the level of effectiveness. The study also carried out a comparative analysis of the financial performance of the banks belonging to three different sectors in terms of three profitability ratios: Return on asset, return on equity and profit expense ratio. The findings concluded that private banks had a high level of financial performance, public banks had moderate level of financial performance whereas islamic banks were found to have low financial performance. Linking the results of the comparative analysis of internal control effectiveness with that of financial performance of the banks indicates that banks that have adopted a strong system of internal control also have high levels of financial performance. Hence, it can be concluded that a sound system of Internal control has a positive relationship with the financial stability of the banks.

Although the Internal control systems was found to be effective in the private banks and a satisfactory level of financial performance is attained, there is still room for efforts to be intensified by the management as well as employees of the bank to develop their control system to achieve greater performance. The control environment can be further strengthened by the top management to provide a strong base for better functioning of the other four components. As far as the Public sector is concerned, banks belonging to this particular sector did not have an effectively functioning control system and had a moderate level of financial performance, attention needs to be given to the two components i.e. control activity and monitoring, that were found to be weak. These banks should enforce job rotation as it helps identify any hidden inefficiencies and errors and exposes any potential weakness in the control system. Moreover, the 
management must ensure that periodic assessments are carried out regularly to report any weaknesses or failing promptly. According to the findings obtained from this study, Islamic banks are lagging quite behind private and public sector banks in terms of control system effectiveness as well as financial performance. The main reason behind this was absence of proper functioning of the four components of internal control. Hence, Islamic banks should take serious measures to strengthen their control system by focusing basic elements like code of conduct, policies, reward systems, identification and mitigation of potential risks, carry out job rotation and establish reliable channels of communication for best decision making. All these efforts will significantly contribute towards strengthening the control system and improving financial accountability.

\section{ACKNOWLEDGEMENT}

First of all with a profound gratitude, we are thankful to Almighty Allah forgiving us success, knowledge and understanding without which we would not been capable of completing this research paper.

We are also profoundly grateful to all our family members whose endurance and understanding have played a significant role in our success by sacrificing the important family time and supporting us all over the research work.

We are finally thankful to the editor, reviewers and IBT specially who provided us with the opportunity to publish our research paper in this esteemed journal.

\section{REFERENCES}

Akosile. (2013). A Comparative Assessment of Internal Control System in Public and Private Universities in South-West, Nigeria. Research Journal of Finance and Accounting, Vol.4, 25-33.

Angella., \& Eno. (2009). Evaluation of Internal Control Systems: A Case study from Uganda. International Research Journal of Finance and Economics, 27, 124-144.

Babatunde., \& Shakirat. (2013). Stakeholders perception on the effectiveness of Internal control system on financial accountability in the Nigerian public sector. International Journal of Business and Management Invention, 2, 1633.

Dana., Jason., \& Nathaniel. (2012). How Effective are Organizations' Internal Controls? Insights into Specific Internal Control Elements. American Accounting Association, 6, 31-50.

Dr. Tamer., \& Dr. Daas. (2013). Assess the extent of the application Internal Control elements evaluation and its effectiveness when doing Audit process- An analytical study on the Jordanian Banks Auditors.

Interdisciplinary Journal of Contemporary Research in Business, 5, 416-435.

Dumitrascu., \& Savulescu. (2012). Internal Control and the Impact on Corporate Governance, in Romanian Listed Companies. Journal of Eastern Europe Research in Business and Economics, 12, 1-10.

Eko Suyono., \& Eko Hariyanto. (2012). Relationship between Internal Control, Internal Audit, and Organization Commitment with Good Governance: Indonesian Case. China-USA Business Review, 11, 1237-1245. 
Emmanuel., \& Agyapong. (2013). Internal Control in Small and Microenterprises in the Vhembe District, Limpopo Province, South Africa. European Scientific Journal, 9, 241-251.

Enwelum. (2013). Examining the Relationships between Internal Control Effectiveness and Financial Performance in the Nigerian Banking Industry. Dissertation Abstracts International, 6, 1-123.

Fawzi., \& Atala. (2012). Internal Control and Audit program effectiveness: Empirical Evidence from Jordan. International Business Research, 5, 128-137.

Francis., \& Samuel. (2013). Internal Control on Cash Collection: A Case Study of the Electricity Company of Ghana Ltd, Accra East Region. International Journal of Business and Social Science, 4, 217-233.

Jianfei., \& Lu. (2011). Analysis of the Relationship between Listed Companies' Earnings Quality and Internal Control Information Disclosure. Modern Economy, 2, 893-900.

Joseph,. Ransome,. \& Victoria. (2012). Effectiveness of Internal Control Systems of Listed Firms in Ghana. Accounting in Africa, 12, 31-49.

Kanyamon., \& Sumalee. (2011). How does internal control effectiveness create reliability of financial reporting? An empirical research of Thai listed firms. Journal of Academy of Business and Economics, 11,

Ngwenya. (2013). Application of Internal Controls in NGOs: Evidence from Zimbabwe. Journal of Finance and Accounting, 1, 39-47.

Olaoye. (2009). Impact of Internal Control System in Banking Sector in Nigeria. Pakistan Journal of Social Sciences, 6(4), 181-189.

Qaisar., \& Javid. (2012) Internal Control System: Analyzing Theoretical Perspective and Practices. Middle-East Journal of Scientific Research, 12(4), 530-538.

Rokeya., \& Muhammad. (2011). Evaluation of Internal Control Structure: Evidence from six listed banks in Bangladesh. ASA University Review, 5, 71-81.

Saidu., \& Zabedah. (2013). Impact of the Effective Internal Control System on the Internal Audit Effectiveness at Local Government Level. Journal of Social and Development Sciences, 4, 16-23.

Uket., \& Joseph. (2012). The Impact of Internal Control Design on Bank's ability to investigate Staff Fraud, and Lifestyle and Fraud Detection in Nigeria. International Journal of Research in Economics and Social Sciences, 2, 32-43.

Ziad., Osama., \& Madher. (2014) The Extent of Employee's Compliance to the Internal Control System on the Reliability and Creditability of Financial Statements. Journal of Scientific Research and Reports, 3(7), 939-952.

Annual reports of Bank AlFalah of Financial years 2010, 2011, 2012 and 2013. Annual reports of HBL of Financial years 2010, 2011, 2012 and 2013 Annual reports of Meezan bank of Financial years 2010, 2011, 2012 and 2013. Annual reports of NBP of Financial years 2010, 2011, 2012 and 2013. 


\section{APPENDIX}

Table I Correlation

\begin{tabular}{|l|c|c|c|c|}
\hline \multirow{2}{*}{} & \multicolumn{2}{|c|}{ MCB } & \multicolumn{2}{c|}{ HBL } \\
\cline { 2 - 5 } & $\begin{array}{l}\text { Magnitude } \\
\text { and Direction }\end{array}$ & $\begin{array}{l}\text { Sig. (2- } \\
\text { tailed) }\end{array}$ & $\begin{array}{l}\text { Magnitude and } \\
\text { Direction }\end{array}$ & $\begin{array}{l}\text { Sig. (2- } \\
\text { tailed) }\end{array}$ \\
\hline $\begin{array}{l}\text { Control } \\
\text { Environment }\end{array}$ & .760 & .000 & .673 & .000 \\
\hline Risk Assessment & .897 & .000 & .847 & .000 \\
\hline Control Activity & .898 & .000 & .814 & .000 \\
\hline $\begin{array}{l}\text { Information \& } \\
\text { communication }\end{array}$ & .822 & .000 & .814 & .000 \\
\hline Monitoring & .596 & .000 & .608 & .000 \\
\hline
\end{tabular}

Table II Correlation

\begin{tabular}{|l|c|c|c|c|}
\hline \multirow{2}{*}{} & \multicolumn{2}{|c|}{ NBP } & \multicolumn{2}{c|}{ SINDH BANK } \\
\cline { 2 - 5 } & $\begin{array}{l}\text { Magnitude } \\
\text { \& Direction }\end{array}$ & $\begin{array}{l}\text { Sig. (2- } \\
\text { tailed) }\end{array}$ & $\begin{array}{l}\text { Magnitude } \\
\text { \& Direction }\end{array}$ & $\begin{array}{l}\text { Sig. (2- } \\
\text { tailed) }\end{array}$ \\
\hline Control Environment & .648 & .000 & .572 & .000 \\
\hline Risk Assessment & .634 & .000 & .559 & .000 \\
\hline Control Activity & .332 & .051 & .488 & .003 \\
\hline $\begin{array}{l}\text { Information \& } \\
\text { communication }\end{array}$ & .667 & .000 & .655 & .000 \\
\hline Monitoring & .590 & .000 & .507 & .002 \\
\hline
\end{tabular}

Table III Correlation

\begin{tabular}{|l|c|c|c|c|}
\hline \multirow{2}{*}{} & \multicolumn{2}{|c|}{ BANK ALFALAH } & \multicolumn{2}{c|}{ MEEZAN BANK } \\
\cline { 2 - 5 } & $\begin{array}{l}\text { Magnitude } \\
\text { and Direction }\end{array}$ & $\begin{array}{l}\text { Sig. (2- } \\
\text { tailed) }\end{array}$ & $\begin{array}{l}\text { Magnitude } \\
\text { and Direction }\end{array}$ & $\begin{array}{l}\text { Sig. (2- } \\
\text { tailed) }\end{array}$ \\
\hline $\begin{array}{l}\text { Control } \\
\text { Environment }\end{array}$ & .564 & .000 & .119 & .497 \\
\hline Risk Assessment & .355 & .037 & .576 & .000 \\
\hline Control Activity & .322 & .059 & .267 & .122 \\
\hline $\begin{array}{l}\text { Information \& } \\
\text { communication }\end{array}$ & .289 & .092 & .164 & .346 \\
\hline Monitoring & .663 & .000 & .562 & .000 \\
\hline
\end{tabular}


Table IV Internal control Effectiveness Comparison in Type of banks with subset

\begin{tabular}{|l|c|c|}
\hline & Mean Scores & Significance \\
\hline Public Banks & 102.7 & \multirow{2}{*}{0.082} \\
\hline Private Banks & 105.5 & \\
\hline Islamic Banks & 98.8 & \\
\hline
\end{tabular}

Table V ANOVA

\begin{tabular}{|l|c|r|r|r|}
\hline \multicolumn{5}{|c|}{ Internal Control Effectiveness } \\
\cline { 1 - 4 } & $\begin{array}{c}\text { Sum of } \\
\text { Squares }\end{array}$ & \multicolumn{1}{c|}{ Df } & $\begin{array}{c}\text { Mean } \\
\text { Square }\end{array}$ & \\
\hline Between Groups & 1607.324 & 2 & 803.662 & \multirow{2}{*}{.000} \\
\cline { 1 - 3 } Within Groups & 12132.871 & 207 & 58.613 & \\
\cline { 1 - 4 } Total & 13740.195 & 209 & & \\
\hline
\end{tabular}

Table VI Return on Asset Comparison in Type of banks with subset

\begin{tabular}{|l|c|c|}
\hline & Mean Scores & Significance \\
\hline Public Banks & 0.0175 & 0.241 \\
\cline { 1 - 2 } Private Banks & 0.02 & \\
\cline { 1 - 2 } Islamic Banks & 0.0125 & \\
\hline
\end{tabular}

Table VII ANOVA

\begin{tabular}{|l|r|r|r|r|}
\hline \multicolumn{7}{|c|}{ Return on Asset } \\
\cline { 1 - 4 } & $\begin{array}{c}\text { Sum of } \\
\text { Squares }\end{array}$ & \multicolumn{1}{|c|}{ Df } & \multicolumn{1}{c|}{$\begin{array}{c}\text { Mean } \\
\text { Square }\end{array}$} & \multirow{2}{*}{ Sig. } \\
\hline Between Groups & .000 & 2 & .000 & \multirow{2}{*}{0.259} \\
\cline { 1 - 4 } Within Groups & .002 & 21 & .000 & \\
\hline Total & .002 & 23 & & \\
\hline
\end{tabular}


Table VIII Return on Asset Comparison in Type of banks with subset

\begin{tabular}{|l|c|c|}
\hline & Mean Scores & Significance \\
\hline Public Banks & 0.4725 & \multirow{2}{*}{0.751} \\
\cline { 1 - 2 } Private Banks & 1.4038 & \\
\cline { 1 - 2 } Islamic Banks & 0.2438 & \\
\hline
\end{tabular}

Table IX ANOVA

\begin{tabular}{|l|r|r|r|r|}
\hline \multicolumn{5}{|c|}{ Return On Equity } \\
\cline { 1 - 4 } & $\begin{array}{c}\text { Sum of } \\
\text { Squares }\end{array}$ & \multicolumn{1}{|c|}{ Df } & \multicolumn{1}{c|}{$\begin{array}{c}\text { Mean } \\
\text { Square }\end{array}$} & \multirow{2}{*}{ Sig. } \\
\hline Between Groups & 6.040 & 2 & 3.020 & \multirow{2}{*}{.003} \\
\cline { 1 - 4 } Within Groups & 8.324 & 21 & .396 & \\
\hline Total & 14.365 & 23 & & \\
\hline
\end{tabular}

Table X Profit Expense Ratio Comparison in Type of banks with subset

\begin{tabular}{|c|c|c|}
\hline & Mean Scores & Significance \\
\hline Public Banks & 1.0950 & 0.116 \\
\hline Private Banks & 1.3612 & \\
\hline Islamic Banks & 0.4875 & \\
\hline
\end{tabular}

Table XI ANOVA

\begin{tabular}{|l|r|r|r|r|}
\hline \multicolumn{5}{|c|}{ Profit Expense ratio } \\
\hline & $\begin{array}{c}\text { Sum of } \\
\text { Squares }\end{array}$ & \multicolumn{1}{|c|}{ Df } & $\begin{array}{c}\text { Mean } \\
\text { Square }\end{array}$ & \multicolumn{1}{c|}{ Sig. } \\
\hline Between Groups & 3.209 & 2 & 1.605 & .020 \\
\hline Within Groups & 7.080 & 21 & .337 & \\
\hline Total & 10.289 & 23 & & \\
\hline
\end{tabular}

